\title{
Effect of growth hormone on semen parameters, partial hemogram, and testosterone level in Nili Ravi buffalo bulls
}

\author{
Masood, A.; Ahmad, I.; Ahmad, N.; Qureshi, Z.I.; Zubair, M. \\ Department of Theriogenology, University of Agriculture, \\ Faisalabad, Pakistan. E-mail: drzubairabbasi@gmail.com
}

\begin{abstract}
Masood, A.; Ahmad, I.; Ahmad, N.; Qureshi, Z.I.; Zubair, M.: Effect of growth hormone on semen parameters, partial hemogram, and testosterone level in Nili Ravi buffalo bulls. Rev. vet. 27: 2, 98-102, 2016. The purpose of this trial was to examine the possible effects of exogenous growth hormone (GH) on semen quality, hematological variables and serum testosterone concentration in Nili Ravi buffalo. Bulls of the treatment group $(n=3)$ were injected with recombinant GH $500 \mathrm{mg}$ in a 15 day interval for 10 consecutive weeks, while bulls of control group $(n=3)$ received equal volume of normal saline solution. Semen samples were collected twice per week and analyzed for physiological parameters. Blood samples collected fortnightly were analyzed for red blood cells count (RBC), hemoglobin concentration $(\mathrm{Hb})$, packed cell volume (PCV), mean corpuscular volume (MCV), white blood cell (WBC), neutrophils, lymphocytes, and serum testosterone levels. Data were analyzed statistically using t-test. Results indicated that GH treatment of Nili-Ravi buffaloes significantly $(\mathrm{p}<0.05)$ increased ejaculatory volume $(8.8 \pm 0.2$ vs $7.7 \pm 0.2 \mathrm{ml})$, sperm motility ( $72.6 \pm 0.4$ vs $67.4 \pm 0.7 \%$ ), mass activity ( $3.35 \pm 0.07$ vs $2.52 \pm 0.08)$, sperm concentration ( $982.2 \pm 67.8$ vs $731.9 \pm 50.5$ million $/ \mathrm{ml})$, live sperm $(80.1 \pm 0.3$ vs $75.8 \pm 0.5 \%)$ and serum testosterone $(4.02 \pm 0.21$ vs $2.37 \pm 0.07$ $\mathrm{ng} / \mathrm{ml}$ ) compared to control bulls. Among hematological variables, lymphocytes were increased $(\mathrm{p}<0.05)$, but MCV, WBC count, and neutrophils decreased $(\mathrm{p}<0.05)$. Hb, RBC and PCV remained unchanged. However, values of these variables were within normal ranges for buffalo bulls. In conclusion, treatment of Nili-Ravi bulls with GH improved semen quality and increased serum testosterone without ostensible adverse effects on the general state..
\end{abstract}

Key words: buffalo, somatotropin, semen, blood, testosterone.

\begin{abstract}
Resumen
Masood, A.; Ahmad, I.; Ahmad, N.; Qureshi, Z.I.; Zubair, M.: Efecto de la hormona de crecimiento sobre los parámetros seminales, el hemograma parcial y el nivel de testosterona en búfalos Nili Ravi. Rev. vet. 27: 2, 98-102, 2016. El propósito de este ensayo fue examinar los posibles efectos de la hormona de crecimiento exógena $(\mathrm{GH})$ sobre la calidad del semen, algunas variables del hemograma y la concentración de testosterona en suero de toros bubalinos Nili Ravi. Los búfalos del grupo tratado $(\mathrm{n}=3$ ) fueron inyectados con $500 \mathrm{mg}$ de somatotropina recombinante cada 15 días durante 10 semanas consecutivas, mientras que los del grupo control $(\mathrm{n}=3)$ recibieron igual volumen de solución fisiológica salina. Las muestras de semen fueron tomadas dos veces por semana y analizadas para evaluar los parámetros fisiológicos. Las muestras de sangre colectadas quincenalmente fueron analizadas para establecer el recuento de glóbulos rojos, la concentración de hemoglobina, el hematocrito, el volumen corpuscular medio (MCV), recuento de glóbulos blancos (WBC), tasa de neutrófilos y linfocitos, así como los niveles séricos de testosterona. Los datos obtenidos fueron analizados estadísticamente por medio del test-t de Student. Los resultados indicaron que el tratamiento con somatotropina aumentó significativamente $(\mathrm{p}<0,05)$ el volumen eyaculado $(8,8 \pm 0,2$ versus $7,7 \pm 0,2 \mathrm{ml})$, la motilidad del semen ( $72,6 \pm 0,4$ versus $67,4 \pm 0,7 \%$ ), la actividad de masa (3,35 $\pm 0,07$ versus $2,52 \pm 0,08$ ), la concentración de espermatozoides ( $982,2 \pm 67,8$ versus $731,9 \pm 50,5$ millones $/ \mathrm{ml})$, los espermatozoides vivos $(80,1 \pm 0,3$ versus $75,8 \pm 0,5 \%)$ y el nivel de testosterona sérica $(4,02 \pm 0,21$ versus $2,37 \pm 0,07 \mathrm{ng} / \mathrm{ml}$ ), comparados con los animales controles. En el hemograma aumentaron los linfocitos $(\mathrm{p}<0,05)$ y disminuyeron variables como volumen corpuscular medio, recuento de leucocitos y tasa de neutrófilos $(\mathrm{p}<0,05)$. Hemoglobina, concentración de eritrocitos y hema-
\end{abstract}


tocrito permanecieron inalterados. Todos los parámetros investigados se situaron dentro de los rangos normales para toros bubalinos. En conclusión, el tratamiento de búfalos Nili-Ravi con somatotropina mejoró la calidad del semen y aumentó la testosterona sérica, sin provocar ostensibles efectos adversos en el estado general de los toros.

Palabras clave: búfalo, somatotropina, semen, sangre, testosterona.

\section{INTRODUCTION}

Growth hormone $(\mathrm{GH})$ is produced by somatotroph cells of the anterior pituitary gland. GH discharge is regulated by the contrasting activities of somatostatin and growth hormone releasing factor. Growth hormone substitution remedies have become popular to overcome ageing process ${ }^{24}$.

Scientists also proclaimed that use of this hormone in the growth hormone deficient patients resulted in obesity reduction, muscle heap proliferation, augmented bone compactness, improved vigor, reproductive efficiency and immunity ${ }^{3}$. The major functions of growth hormone include milk production and expression of IGF-1 genes in the liver along with augmentation of testosterone action in maintenance of spermatogenesis in hypo-physectomized animals.

Growth hormone receptors have been identified in male reproductive organs including vas deference, accessory glands, epididymis, Sertoli and Leydig cells. Moreover, other researchers reported that the treatment of adult bulls with bovine somatotropin improved the ejaculate volume, concentration and morphology of sperm $^{5}$.

It has been observed that growth hormone treatment improved storage life of bovine spermatozoa without any harmful effect on their motility ${ }^{17}$. Bulls treated with recombinant bovine somatotropin (rbST) revealed higher pre and post freezing sperm motility as compared to control bulls ${ }^{22}$.

Growth hormone gene had a significant effect on libido score, flehmen response, spermatozoa mass activity, number of semen doses per collection, individual fresh sperm motility, post thaw sperm motility, acrosome integrity, plasma membrane integrity, live sperm (\%) and morphologically abnormal sperm in crossbred bulls ${ }^{19}$.

A recent study showed that treatment of Sahiwal bulls with $500 \mathrm{mg}$ rbST weekly for 10 weeks improved libido, increased serum testosterone, total leukocytes count and serum globulin ${ }^{7}$. However, there is relatively little information regarding the effects of long-term treatment with exogenous growth hormone on reproductive functions in bulls.

In the present study, the possible effects of rbST (BoostinTM-S) on semen parameters, serum testosterone concentrations and hematological parameters in adult Nili Ravi breeding bulls were investigated.

\section{MATERIAL AND METHODS}

Animals. The present study was carried out on six adult Nili Ravi buffalo bulls, with clinically normal reproductive tract and kept at the Semen Production Unit, Qadrabad, Sahiwal, Pakistan. The age of these bulls ranged from 5-10 years. All animals were housed in free stall barn, fed $2 \mathrm{~kg} /$ bull/day concentrate ration with seasonal fodder ad libitum, and free access to drinking water.

Experimental design. The six bulls were assigned randomly into two groups. Control group $(n=3)$ : the bulls in this group were kept as control and were injected with normal saline as placebo treatment. Treated group $(n=3)$ : each bull in this group was injected with $500 \mathrm{mg}$ rbST subcutaneously fortnightly for 10 weeks ${ }^{2}$.

Semen samples were collected twice weekly with two ejaculates per collection for 14 weeks $\left(1^{\text {th }}\right.$ week pretreatment period, 10 weeks treatment period, and 3 weeks post treatment period) from each animal, by means of an artificial vagina and using an intact bull as teaser. Thus, a total of 168 semen ejaculates (28 semen ejaculates/bull) were collected from six bulls during the experimental period (late february to early june, 2014).

Immediately after collection, semen samples were evaluated for volume, mass activity, sperm motility percentage, sperm viability, and sperm concentration. Semen volume was recorded directly from graduated test tubes. The mass activity of spermatozoa was recorded immediately after collection by examining a drop of semen on a warm slide at 100x magnification under a microscope with attached stage warmer (temperature set at $37^{\circ} \mathrm{C}$ ). Motility percentage was estimated for fresh semen by examining a drop of semen (with $2.9 \%$ sodium citrate solution), under microscope at $400 x$.

For sperm concentration spectrophotometer (IMVphotometer) was used. A sample of semen $(0.02 \mathrm{ml})$ was diluted with physiological solution $(\mathrm{NaCl} 0.9 \%)$ and placed in a macro-cuvette. The result was recorded from photometer screen ${ }^{4}$. The live and dead sperm ratio was determined by mixing a drop of semen with a drop of eosin-nigrosin stain on pre-warmed slide ${ }^{23}$.

Blood sampling was performed fortnightly during the 10 weeks treatment period. About $15 \mathrm{ml}$ blood was collected and divided into two fractions. About $5 \mathrm{ml}$ blood was placed in EDTA plain vacutainer tubes for 
determination of hematological variables viz. RBC, $\mathrm{Hb}, \mathrm{PCV}, \mathrm{MCV}, \mathrm{WBC}$, neutrophils (\%) and lymphocytes (\%), using standard procedures ${ }^{6}$.

The remaining $10 \mathrm{ml}$ blood was used to get serum for analysis of serum testosterone level ${ }^{21}$. The concentration of testosterone was determined through ELISA, based on the principle of competitive binding between testosterone in the sample and testosteroneHRP (horseradish peroxidase) conjugated for a constant amount of rabbit anti-testosterone.

Statistical analysis. Mean values $( \pm \mathrm{SE})$ for various parameters of semen quality, serum testosterone and hematological variables of bulls of two groups, were computed. Student's t-test was applied to ascertain magnitude of variation in various parameters between bulls of the two groups ${ }^{11}$.

\section{RESULTS AND DISCUSSION}

Semen quality parameters. The overall mean value for semen volume was significantly higher in treated bulls compared to control ones (Table 1). The similar kind of results was present in Holstein Friesian bulls ${ }^{12}$. It is well known that fluid part of the semen is contributed by the accessory sex glands, especially seminal vesicle and prostate gland. It seems that exogenous growth hormone stimulates the secretory activity of these glands, resulting in increased ejaculatory volume in treated bulls compared to controls ${ }^{22}$.

In this investigation, results indicated that motility in rbST treated buffalo bulls was significantly higher compared to control group (Table 1). Other authors also reported that rbST treatment increased the motility in treated lambs ${ }^{9}$. This increase in sperm motility percentage due to rbST treatment can be attributed to increase level of testosterone.

Mass activity was significantly higher $(\mathrm{p}<0.05)$ in rbST treated bulls compared to control bulls. It was reported a significant increase in mass activity in GH (rbST $500 \mathrm{mg}$ ) treated Friesian bulls than control group $^{12}$. Mass activity in an ejaculate mainly depends upon individual sperm motility and sperm concentration, both of which were increased due to rbST treatment. Thus, this increase in mass activity may be due to increased individual motility and concentration of spermatozoa in the ejaculates of rbST treated bulls.

In rbST treated buffaloes, sperm concentration was significantly higher than control group of bulls (Table 1). Other authors also concluded that rbST treatment $(500 \mathrm{mg})$ increased the sperm concentration in rbST treated Friesian bulls compared to controls ${ }^{12}$. The increase in sperm concentration attributed due to the effect that GH increases the testicular mass, which in turn increases the sperm production ${ }^{13}$.

Percentage of live spermatozoa was significantly higher in rbST treated Friesian bulls as compared to control bulls. These results are supported by authors who reported increase in live sperm in rbST treated
Table 1. Values of semen parameters, testosterone levels and hematological profile in Nili Ravi bulls.

\begin{tabular}{lcc}
\hline parameter & control group & treated group \\
\hline semen volume $(\mathrm{ml})$ & $7.69 \pm 0.21^{\mathrm{b}}$ & $8.84 \pm 0.20^{\mathrm{a}}$ \\
mass activity $(0-5)$ & $2.52 \pm 0.08^{\mathrm{b}}$ & $3.35 \pm 0.07^{\mathrm{a}}$ \\
sperm motility $(\%)$ & $67.44 \pm 0.68^{\mathrm{b}}$ & $72.62 \pm 0.36^{\mathrm{a}}$ \\
sperm concentr. $\left(10^{6} / \mathrm{ml}\right)$ & $731.90 \pm 50.51^{\mathrm{b}}$ & $982.22 \pm 67.82^{\mathrm{a}}$ \\
live spermatozoa $(\%)$ & $75.78 \pm 0.51^{\mathrm{b}}$ & $80.14 \pm 0.35^{\mathrm{a}}$ \\
serum testosterone $(\mathrm{ng} / \mathrm{ml})$ & $2.37 \pm 0.07^{\mathrm{b}}$ & $4.02 \pm 0.21^{\mathrm{a}}$ \\
$\mathrm{RBC}$ count $\left(10^{6} / \mu \mathrm{l}\right)$ & 6.34 & $6.59 \pm 0.18$ \\
$\mathrm{Hb}(\mathrm{g} / \mathrm{dl})$ & $15.64 \pm 0.23$ & $15.02 \pm 0.46$ \\
$\mathrm{PCV}(\%)$ & $37.53 \pm 0.64$ & $35.53 \pm 1.24$ \\
$\mathrm{MCV}(\mathrm{fl})$ & $57.40 \pm 0.59^{\mathrm{a}}$ & $53.16 \pm 0.34^{\mathrm{b}}$ \\
$\mathrm{WBC}$ count $\left(10^{3} / \mu \mathrm{l}\right)$ & $10.40 \pm 0.19^{\mathrm{a}}$ & $7.78 \pm 0.46^{\mathrm{b}}$ \\
lymphocytes $(\%)$ & $53.68 \pm 0.72^{\mathrm{b}}$ & $58.64 \pm 1.41^{\mathrm{a}}$ \\
neutrophils $(\%)$ & $35.04 \pm 0.45^{\mathrm{a}}$ & $31.95 \pm 0.58^{\mathrm{b}}$ \\
\hline
\end{tabular}

Values in mean \pm SE. Values with different letters for each parameter differ significantly from each other $(\mathrm{p}<0.05)$.

bulls compared to control ones ${ }^{12}$. This increase in live percentage may be due to better regulation of testicular functions ${ }^{22}$.

The mean serum testosterone was significantly higher in rbST treated bulls as compared to control ones (Table 1). Similar results are present in rams ${ }^{9}$ and bulls ${ }^{7,12}$. The reason for increase in testosterone level was that the exogenous $\mathrm{GH}$ administration increased the number of luteinizing hormone (LH) receptors on the Leydig cells which increase the responsiveness to LH. So, GH makes release of LH from Sertoli cells along with increase in responsiveness of Leydig cells to $\mathrm{LH}$, which acts on Leydig cells to produce testosterone ${ }^{13}$.

Hematological variables. Difference in RBC count between both groups was non significant (Table 1). Similar findings have been reported earlier $15,18,20$. However, others recorded a significant decrease of $\mathrm{RBC}$ count in lactating cows, following treatment with recombinant bovine somatotropin ${ }^{10}$.

Hemoglobin concentration showed a non significant difference in rbST treated and control bulls (Table 1). According to some investigations, slight decrease in $\mathrm{Hb}$ concentration was observed in goats following treatment with rbST $100 \mathrm{mg}$ compared to control. However, when low dose of rbST $50 \mathrm{mg}$ was used, no difference in $\mathrm{Hb}$ values was observed between the two groups ${ }^{20}$.

There was non significant difference in PCV between the two groups, along with it was slightly low in rbST treated group of bulls (Table 1). However, it was reported that in response to rbST treatment $(500 \mathrm{mg}$ at 15 day interval) in Nili Ravi buffaloes, PCV was decreased in treated group compared to control group ${ }^{14}$. Other researchers also observed a decrease in PCV in ewes when they were treated with rbST $(50 \mathrm{mg})$ for two months at 15 day interval, compared to control ${ }^{20}$. This decrease in PCV was attributed to the dilution effect 
of the blood as rbST treatment caused increase in the moisture contents of the carcass as well as in some organs ${ }^{10}$

The MCV value in control bulls was significantly higher compared to rbST treated bulls, but was within normal physiological limits for bovines ${ }^{1}$. The physiological significance of decrease in MCV following rbST treatment remains unclear.

White blood cells count showed significant decrease in rbST treated bulls in comparison to control bulls. However, others observed non significant difference in WBC count between rbST treated and control ewes ${ }^{20}$. In this study, a significant decrease in neutrophils was observed in rbST treated bulls compared to control bulls. Other authors also recorded a significant decrease in neutrophils in rbST treated buffaloes compared to controls ${ }^{14}$. This decrease in neutrophil count might be due to their priming with GH which changes the shape of neutrophils, enhances the adhesion of neutrophils to blood endothelium and increases their oxidative burst of neutrophils. The availability of free neutrophil count in circulation, reduced mainly due to adhesion of neutrophils to blood vessel endothelium.

In this study rbST treatment significantly increased the lymphocyte in buffalo bulls compared to control bulls. Other investigators reported that use of rbST 500 mg biweekly significantly increased the lymphocytes in Nili Ravi buffaloes compared to control buffaloes ${ }^{14}$. According to some reports this increase in lymphocyte count was due to the fact that GH hormone enhanced the development and maturation of lymphocytes by increasing the activity of bone marrow, primary (thymus) and secondary lymphoid tissue (lymph nodes) ${ }^{16}$.

The purpose of hematological study was also to see if rbST treatment has any adverse effect on animal health. Although rbST treatment affected certain hematological parameters but all the hematological parameters were within normal physiological range reported for bovines. So it may be concluded that rbST treatment had no adverse effects on health of bulls.

Previous studies have revealed that rbST treatment improves animal growth performance ${ }^{18}$. Moreover, improvement in semen quality parameters following treatment with rbST has also been reported in Zebu bulls, stallion, buffalo calves, and lambs ${ }^{8,9}$. Thus, besides improving milk yield in female animals, rbST treatment has also beneficial effects on reproductive functions of male ${ }^{20}$.

On the base of findings of this study it can be concluded that GH remarkably enhanced the semen quality in Nili Ravi buffalo bulls. It also improved the serum testosterone level, while it had no adverse effects on health of bulls.

Acknowledgements. Authors are highly thankful for the staff of the Semen Production Unit, Qadirabad, Sahiwal, Pakistan, for their assistance in handling the experimental bulls used in this study.

\section{REFERENCES}

1. Abd Ellah MR, Hamed MI, Ibrahim DR, Rateb HZ. 2014. Serum biochemical and haematological reference intervals for water buffalo (Bubalus bubalis) heifers. J South Afr Vet Ass 85: 962-967.

2. Ahmed RM, Kandiel MM, Sosa AG, Abou EA, Abdel AE, El-Azab AS. 2011. Effect of GnRH analogue on libido and semen characteristics of pubertal buffalo bulls. Benha Vet Med J 1: 28-34.

3. Bauman DE. 1992. Bovine somatotropin: Review of an emerging animal technology. J Dairy Sci 75: 3432-3451.

4. Borge LV, Pedersen PN. 1996. Evaluation of sperm concentration in boar semen using spectrophotometer and fluorometer. Repr Dom Anim 37: 259-266.

5. Bousquet D, Isabelle M, Brindle Y, Dubreuil P. 2004. Effect of growth hormone (bST) on semen production in bulls. Proc. 23th World Biuretic Congress, Quebec City, Canada, p. 831 .

6. Coles EH. 1986. Veterinary Clinical Pathology, $4^{\text {th }}$ ed., Saunders, London, UK.

7. Dilbar GH et al. 2014. Effects of bovine somatotropin on libido, serum testosterone, hematology and certain biochemical metabolites of Sahiwal bulls. Pakistan J Agric Sci 51: 501-506.

8. El-Aziz NA, Youssef MM, El-Malky OM, Abdel AM. 2009. Growth aspects, pubertal attainment and semen characteristics of buffalo calves treated with somatotropin under different climatic conditions. Proceed 2nd Scient Conf Anim Wealth Res, Cairo, Egypt, p. 69-81.

9. El-Gohary ES, Khalek A, Ashmawy TA, Teleb DF, Sallam AA. 2011. Effect of recombinant bovine somatotropin on growth performance and puberty incidence of male and female lambs born from rbST treated ewes. Egypt J Sheep Goat Sci 6: 47-57.

10. Eppard PJ, White TC, Sorbet RH, Weiser MG, Cole WJ, Hartnell GF, Intz RL, Lanza GM, Vicini JL, Collier RJ. 1997. Effect of exogenous somatotropin on hematological variables of lactating cows and their offsprings. $J$ Dairy Sci 80: 1582-1591.

11. Fay MP, Proschan MA. 2010. Wilcoxon-Mann-Whitney or $t$-test? On assumptions for hypothesis tests and multiple interpretations of decision rules. Stat Surv 4: 1-39.

12. Hafez M, Fawzy SA, El-Henawy MA, Barkawi AH. 2005. Effect of recombinant bovine somatotropin on semen physical characteristics and some biochemical constituents in seminal plasma of Friesian bulls. Egypt J Anim Prod 42: 87-94.

13. Hamidi A, Mamoei M, Mirzadeh K, Tabatabaei S, Roshanfekr HA. 2011. Correlation between blood growth hormone profile and reproduction performance in Arabic rams. Comp Clin Pathol 21: 819-823.

14. Khaliq T, Rahman ZU. 2010. Haematological studies of Nili-Ravi buffaloes injected with recombinant bovine somatotropin. Pakistan Vet J 30: 53-57.

15. Kweon UG, Nam KT, Kim HS, Yun SK, Kim SJ, Hong BJ. 2000. Effects of rbST (recombinant bovine somatotropin) injection time on haematological values and blood 
metabolic substrates in Holstein steers. Korean Anim Sci 42: 269-278.

16. Lisbeth A, Sun WR, Murphy WJ. 2002. The role of growth hormone in T-cell development and reconstitution. J Leuk Biol 71: 381-387.

17. Magon N, Singh S, Saxena A, Sahey R. 2011. Growth hormone in male infertility. Indian $J$ Endocr Metab 15: 248-249.

18. Nour AN, El-Zarkouny SZ, Ghobashy H, Abdel EI, Kesler DJ. 2009. Growth, hematological and biochemical responses of growing lambs injected with growth hormone and supplemented with calcium soaps of fatty acids. South Afr J Anim Sci 41: 183-192.

19. Pal A, Chakravarty AK, Chatterjee PN. 2013. Polymorphism of growth hormone gene and its association with seminal and sexual behavioral traits in crossbred cattle. Theriogenol 83: 474-480.

20. Sallam SM, Nasser ME, Yousef MI. 2007. Effect of recombinant bovine somatotropin administration on milk production, composition and some hemato-biochemical parameters of lactating goats. Semin Mediterr Serie A 74: 291-297.
21. Sarkar M, Dutta BK, Bandopadhyay S, Meyer HH, Prakash BS. 2009. Season of the year influences semen output and concentrations of testosterone in circulation of yaks (Poephagus grunniens.L). Anim Reprod Sci 115: 300305.

22. Sauerwein H, Breier BH, Gallaher BW, Gotz C, Kufner G, Montag T. 2000. Growth hormone treatment of breeding bulls used for artificial insemination improves fertilization rates. Domest Anim Endocr 18: 145-158.

23. Sergey IM, Clifford LL. 2012. Spermatogenesis: methods of sperm vitality assessment 927: 13-19.

24. Tuggle CK, Trenkle A. 1996. Control of growth hormone synthesis. Domest Anim Endocr 13: 1-33.

\section{SClmago Journal \& Country Rank}

\section{Powered by SCEPUS}

\section{Revista Veterinaria aumentó su índice de impacto}

Noticias de Scimago Research Group (Scimago Journals \& Country Ranks, Scopus-Elsevier) comunican que la publicación de nuestra casa, Revista Veterinaria, aumentó su índice de impacto. El índice SJR mide la influencia científica (impacto) del artículo de una revista, expresando cuán importante es el "artículo promedio" de la publicación en la discusión científica global (sistema Thomson Reuters).

Para nuestra revista, tal indicador había sido de 0,03 entre 2008 y 2011, aumentando a 0,05 en 2012 y a 0,11 en 2013, último período evaluado. El aumento fue del 370\%. Asimismo, surge para nuestra publicación un sostenido descenso del indicador que relaciona "citas versus autocitas", demostrando que los autores de los artículos están abandonando la práctica de citar sus propias publicaciones anteriores.

Por último, se advierte que según este portal, nuestra "Revista Veterinaria" continúa siendo la única publicación de esta rama de la ciencia que posee índice de impacto en Argentina. Para el resto del cono sur tal distinción recae en Brasil, Chile, Colombia y Venezuela. No registran índice de impacto las revistas de veterinaria de Bolivia, Paraguay, Uruguay, Perú y Ecuador. En revistas de veterinaria, a nivel mundial el mayor índice de impacto (1,22 puntos) recae en Veterinary Microbiology (Amsterdam, Holanda).

Fuente:

http://www.scimagojr.com/journalrank.php?area $=0 \&$ category $=0 \&$ country $=$ AR\&year $=2012 \&$ order $=$ sjr $\&$ min $=0 \&$ min_type $=$ cd Retrieved April 4, 2014 